\title{
Mystical Representation of Death in the Poetry of John Donne and Abul-Alaa Al-Ma'arri: A Comparative Study
}

\author{
AmatulHafeez Alvi', Rahma Alvi ${ }^{2}$, Ateqa Abdul Rahim Alvi ${ }^{3}$ \\ College of Languages \& Translation, Abha. King Khalid University. Saudi Arabia ${ }^{1}$ \\ College of Sciences \& Arts, Khamis Mushait. King Khalid University. Saudi Arabia ${ }^{2}$ \\ Minhaj College for Women, Lahore. Minhaj University. Pakistan ${ }^{3}$ \\ Corresponding Email: Alvi.amt@gmail.com ${ }^{1}$
}

Submitted: $28 / 12 / 2020$

Revised: 01/01/2021

Accepted: 24/01/2021

E-ISSN : $2579-4574$

P-ISSN : 2549-7359

\begin{abstract}
This paper is a comparative descriptive investigation of the mystical representation of death in the poetry of the English poet John Donne and the Arabic poet AbulAlaa Al-Ma'arri. Highlighting their life circumstances and the religious, intellectual, economic and psychological factors that shaped their specific perceptions of Death, the study reflects upon the mystic elements in both poets' approach towards Death and delves deeper into the language they adopted to express their insights. The death poetry of both poets has been previously studied from different individual perspectives, but none has approached it comparatively from a mystical stylistic viewpoint. Using the major echelons of mysticism implemented by both poets in the treatment of death in the selected death poems such as contemplation, escapism, compulsion, conscience, tranquility, submission and reunion, the study implements a comparative content and stylistic analysis methodology to analyze linguistic and literary representation of death in the selected poems. It identifies the similarities and differences between both poets and concludes that despite the cultural and religious, time and place differences, both poets share psychological and intellectual factors that lead them towards the identical mystical perception of Death as an agent for unity with the Ultimate Divinity. This perception has been gradually developing and masterfully represented with the use of linguistic techniques like imagery, apostrophe, metaphors, personification, symbolism, allusion. and logical construction. The study hopes to fill a vital gap in the body of knowledge related to the mystical perceptions of death and the language that capture the identity of the two poets in their timeless literary masterpieces.
\end{abstract}

Keywords: Mysticism; Death; Donne; Al-Ma’arri; Comparative.

https://ojs.unm.ac.id/eralingua

This work is licensed under a Creative Commons Attribution-NonCommercial 4.0 International License 


\section{INTRODUCTION}

Death is the greatest incident in human life, greater than birth and marriage for the ambiguities that surround it. It has been a riddle that could not be decoded despite the progress of civilization and technology. It is an inexplicable and unknown natural phenomenon which overtakes human body and there is no reliable answer for why how when and where and to whom it may occur. Literature has been participating in the endeavors to answer these questions and helping people to conceive this definite "ending".

Death has been present in human philosophies and thoughts since times immemorial. The philosopher Jack Shoron says that ancient humans considered death as a result of malevolent external factors. They did not realize that death is an inevitable necessity for every living organism on earth, but only after the development of their mental abilities and perception which helped them to come to terms with what they saw human dying even without obvious reasons. The French philosopher Voltaire says that the knowledge of the inevitability of death is acquired by humans through their own experiences or through messages from their creator. The Roman philosopher Epictetus said that there is no evil in the universe; until death eventually becomes a good service to nature.

In Babylonian and Assyrian reflections, death was not seen as the absolute end of life or as a complete annihilation of conscious vitality; but it meant the separation of the body and the soul, the dissolution of the former, the transition of the latter from a pattern of life or existence to a pattern or another; the Spirit descends to the underworld to dwell there through eternity.

The Greek philosophers had also pondered upon the ambiguity of death and endeavored to give various explanations. Pythagoras believes in the reincarnation of spirits, he considers the soul to be the prisoner of the flesh which leaves it to purify it and return. At death, soul departs to begin the cleansing of sins, and then returns after this journey of purification to unite with Lord the Creator. The Greek philosopher Heraclitus, who believes in the continuity of life where the grandchild succeeds the father and grandfather, says: life follows death, and the process of creating life from rigid matter will last forever, and the newborn supplants the old. Empedicus also declared his faith in the reincarnation of spirits; he sees that a spirit does not die because its origin is from God and it is eternal. Democritus sees that the soul is destroyed; at death, it turns into minute atoms and then dissipates and ends. Souls were intended to remove the fear of death, the death from punishment, and to plant joy in the soul. Plato said: Death is the liberation of the soul from the body. The soul exists before the birth of man, and it has the character of immortality after death, and has the ability to control the body; it is similar to eternal gods. Aristotle typically argued that we should not fear death, because it is not bad for us. Socrates sees death as not a place of fear. On the other hand, he says that Death is the greatest evil and describes it as a "dreamless sleep" and a journey to another place. Epicurus said that death means the absence of sensation and sees the viability of the soul with the body. 
All religions have widely and differently tackled the topic of death as a common denominator and joint inevitable destination and asserted its reality and inevitability. The earliest Egyptian religion believed on the reality of death and afterlife. According to it, the body dies, and parts of its soul known as ka (body double) and the ba (personality) go to the Kingdom of the Dead. While the soul resides in the Fields of Aaru. Statues were positioned in the tombs to serve as substitutes for the deceased. Egyptians also believed in mummifying as the best way to have a good life after death.

The Greeks religion believed that the Greek gods like Hermes, Charon the messenger of the gods, takes the dead soul of a person to the underworld Hades or the House of Hades). Hermes would leave the soul on the banks of the River Styx, the river between life and death. Once crossed, the soul would be judged by Aeacus, Rhadamanthus and King Minos. The pious souls would be sent to Elysium, and the evil ones will be sent to Tartarus. The Romans had a similar belief system about death and afterlife, god Pluto takes the soul high above the Earth, looking down at the small planet. To the fields of happiness or sorrow according to the deeds.

The Bahá'í Faith states the inability of the livings to understand the reality of death and life hereafter just as a fetus is unable to realize the world outside of the womb. It asserts that the soul is immortal and after death it will continue to progress until it attains God's company. Souls will be accounted for their deeds and will be rewarded according to them. Christianity teaches that death is inevitable and after the body dies, the soul is judged, the righteous and free of sin enter Heaven and those who die in unrepented mortal sin go to hell. Those who die in God's grace and friendship, but still imperfectly purified, are indeed assured of their eternal salvation; but they have to undergo purgation after death to achieve the holiness necessary to enter the joy of heaven.

The Islamic belief confirms death, life in the grave and life in the hereafter either in Paradise Jannah or Hell Jahannam according to the deeds and degree of piety (Iman). Islam teaches that the objective of Man's whole creation is to worship Allah alone, and that the life we live on Earth is nothing but a probation for us and to determine each person's eventual domicile, be it Hell (Jahannam) or Heaven (Jannah) which will be eternal and everlasting. Last Day is a chief doctrine of the Quran , on which the entire world will be demolished, and Allah will resurrect all creatures from the dead to be judged. The Last Day is also called the Day of Standing Up, Day of Separation, Day of Reckoning, Day of Awakening, Day of Judgment, The Encompassing Day or The Hour (Al-Quran).

In Judaism, death theories manifest that men were intended to rule the world, but death comes as punishment to their deeds. The Talmud confirms death and teaches that souls die and brought into the Olam Haba or world to come where their deeds will be brought in front of them. Buddhism sustains that death occurs and rebirth takes place without an unchanging self or soul passing from one form to another. The kind of return will be conditioned by the ethical quality of the person's actions kamma or karma. In Hinduism, the Bhagavan Gita broadly explains death and life after death. The belief is that the body is a shell, the soul inside is 
unassailable and imperishable that takes on different lives in a cycle of birth and death. The end of this cycle is called mukti which means remaining lastly with supreme God forever, referred to as moksha or salvation.

Jainism too has faith in death and the afterlife. It says that the soul takes on a body form based on former karmas or actions committed by that soul through eternity. Jains believe the soul is eternal and that the freedom from the cycle of reincarnation is the means to attain eternal bliss. Sikhism believes that the soul belongs to the spiritual universe which has its origins in God but there is no definite believe in the life hereafter. It is essential dogma is to experience the divine through humble living, meditation and contemplation while being alive. Soul is never born and never dies. It is a part of God and hence lives forever.

Traditional African religions agree on the inevitability of death and vary in their views about what happens after death. Some, like Hadza, believe that there is no life after death at all while others like Yombe, Beng, Yoruba and Ewe believe that the dead come back into life and are reborn into their children. The journey of life and death in mysticism is one of the most fertile journeys in our civilization. Mysticism is a unique creative experiment that represents soul, intuition and life in their most sublime levels. Mysticism denotes religious explanation to death and defines death as the suppression of self-identity. When the desires are suppressed, the soul moves to the holy world of divine love and oneness that does not accept death at all. Plato referred to this death by saying: "He died by will, he lived by nature." The Qur'an says: "He who created death and life" and death includes the previous death on life and the subsequent death. Life includes primary life and afterlife, all of which are created by God as determined in the verse that establishes this truth in human perception.

Mystics only want the face of God. Death is the elixir of life for them. True life is filled with the light of beauty and majesty. Death is the annihilation of existence into the House of Happiness and Immortality. They are a people whose hearts are filled with the love of God and their hearts are filled with burning and longing to meet God. Mysticism has linked love, knowledge and death in close bond, and this indicates that the problem of death has been associated with the general pattern of mysticism. Death has been linked to the world and the Hereafter in close bond and asserts that the wise is the one who repent purely before death. The mystics indorse the question of death in a time when material values dominate spiritual values and try to promote the human soul in the moral field and raising selfconscience and remembrance of death as a major ethical goal.

According to the mystic believe, the target of an accurately lived life, is to behold the truth, the eventual certainty, that releases humans from ignorance in this life and the life hereafter (Underhill, 1955). Salvation and the oneness with God are perpetual quest for mystics which they can attain through knowledge (Ma'rifa). This can be related to the term gnosis, in the Judeo-Christian tradition, which denotes to a specific knowledge of the divine. The famous mystic Ibn Arabi says that achieving a peaceful heart through acts of nobility and generosity guarantees the mystic the peace of having become transferred into God's Ultimate Reality. 
According to Ibn Arabi, a prosperous afterlife can only be achieved by strengthening the relationship with God by realizing His True nature.

Death in Mystical thought denotates three types of death. The first is the spiritual death; a veil from the illuminations of the revelation and the reflection when a person is detached from the mystic sub consciousness and returning to the world of confusions, perceptions of sensuality and loss of the divine benevolences. The other form of death indicates suppressing the whim of the soul as he whose follows his desires is dead, and that who overthrows his desires and lives piously is alive for true life means to have a purified guided soul. The third type denotes actual physical death and leaving the earthly world, and to move to the world hereafter where God's loved ones do not die but move from a temporary life to an eternal blessed life (Turki, 2003).

Generally, Death in mysticism is vanishing in divine love and seclusion from all what distracts from piety and virtue and that life is only in the absolute presence of God. Thus, death in mysticism is an attempt to discover the spiritual element within in order to better understand the meaning of life and death, which reveals that the real life is in the divine presence where souls are absorbed in God, with God and by God, and that true death is not a change imposed on the mind or the body, but the departure and separation of self from the realm of God.

Death is one of the universal mysteries that have been engaging human thoughts since decades and has been poignantly reflected upon in diverse literary genres. Death has a sturdy relation with literature. The sociologist Zygmunt Bauman (1992) claims that although death is the most truthful experience in human life, still it remains incomprehensible, and thus, it requires to be encountered in other ways, such as seeing the death of others, in addition to the help of literature to envisage how it will feel (Bauman, 1992). Walter Benjamin, a German philosopher, and literary critic asserted that "what we seek in fiction is the knowledge of death that is denied to us in the real life" (Brooks, 1943). The theme of death is present with its heaviness and significance in all world literatures and attitudes towards it have been changing and varying according to life circumstances, believes ad social systems. A cross-cultural reading of world multilingual literatures can suggest how much death and related facts of life and existence, has been an obsessing idea, mesmerizing mystery, and alluring charm for writers around the globe.

\section{LITERATURE REVIEW}

Death has been a major theme in English poetry since the Anglo-Saxon period to current modern times. Death prompts anxiety and inquisitiveness since it advances suddenly without any preparations and expectations. It is an absolute yet ambiguous truth that no one likes and looks cruel yet inevitable as it strips from one's family and beloved ones. That's why, Death has been constantly interrogated not only in literature, but also in philosophy and religions. Frank and Judith McMahon stated that "we may have seen death, read about death, or even come close to death, but we may have never died. Thus, we face the ultimate unknown, and the fact that our society refuses to admit that death is a natural process" (Frank and McMahon, 1986). Poets addressed it, contemplated on its sneaky visit. While some have observed it physically, others view it in a spiritual Metaphysical way. 
John Donne (1572-1631) is an eminent English poet who is regarded as the father of Metaphysical poetry. Death has been a constant preoccupation for him that he hardly wrote a poem without referring to it. Donne has gone through many tragedies in life. He lost four of his immediate family members in front of him including his father, brothers and uncles. He has seen the religious conflicts within the Church of England and the harassments and financial penalties on the Catholics during Queen Elizabeth's government. His marriage phase did not go well with his 12 children dying during birth and eventually the death of his wife Ann. He went through sever financial crises and health issues and remained ill and isolated very often. Sugg (2007) remarks: "Throughout his writing [Donne] frequently seems to have not one but two feet firmly in the grave, and indeed digging himself into it with creative zeal" (Sugg,2007, p. 187).

These circumstances had a key role in shaping his philosophy about life and death, so he started approaching death unconventionally and mystically. He started seeking the empirical and pragmatic truth about it and looked at it as an eliminator of fear and pain and an agent for soul's delivery and rest. The image of death and its derivative feelings in John Donne were entirely different from the other's attitude toward death. He believed in existence of life after death and was not afraid of death and seen the actual happy life in the glory of heaven, the promised land of Lord where there is no more death. This notion has been directly and indirectly reflected poignantly in his famous sermons, love songs, sonnets and elegies.

John Donne's death poetry has been the center of literary criticism and investigation. Among the critics is Oliver (1999) who demonstrates Donne's concerns about death as a well-documented and substantial quantity of his work offers references to the subject of death. Oliver focusses on the way Donne changes his opinion, leaving a perplexed reader to attempt to find his real belief on the subject. He assumes that Donne did not fear death in the conventional manner, for he believed in the concept of an afterlife. His faith in Christian theology soothed those fears and doubts, yet he very often searched for answers to questions about death, answers that had no explanation. Therefore, his poetry is extremely paradoxical, a quality that only adds to its magnificence and attractiveness, much to the delight of its readers.

Dickson (2007) examines John Donne's fascination with death as a literary, philosophical, and emotional subject, and explores its presence in his poetry and treatises. Highlighting Donne's key death works like 'A Serious Ailment', 'The Apparition', 'Death Be Not Proud', and 'The Play's Last Scene', Dickson demonstrates how John Donne's writings are 'death-obsessed' and haunted by the theme of mortality. Donne's poems and sermons, says Dickson, "grapple with that biggest question of all; what really happens to us when we die?". Death was Donne's personal obsession as once he wrote that he had a 'sickly inclination' and it was also an 'imaginative prompt' and a way of discovering intense and sometimes frantic feelings, of testing the nature of faith, of probing the boundaries of selfhood and existence.

Fomehshi (2013) investigates the concept of death in Donne's poetry in comparison with that of Sohrab Sepehri from a comparative perspective. The 
studey's main finding is that Both John Donne and Sohrab Sepehri employ death as a subject for their artistic creation because of similar reasons such as the depression and cynicism of spirit; and regarding life as a cheap possession. Both poets witnessed turbulent period in the history of England and Iran. However, Donne is more influenced and obsessed with Death than Sepehri. Also, Donne is inconsistent in his treatment of death as he vacillated between two poles. As a religious preacher, he has a positive attitude toward death, but as soon as he loses a beloved, his attitude changes. While Sepehri is more consistent in his positive treatment of death based on his mystic and religious beliefs.

Patal (2015) investigates the theme of death in one of his most famous poems "Death Be Not Proud", appreciating how he explains his readers the real status of the death in human's life providing a kind of eternal knowledge to his readers like a reasoned philosopher. To Donne, asserts Patash, Death is not a conqueror so one should never get afraid of it. Life and death are in the hands of god so death will only come to those when it is summoned by god. Donne here adds one more thing that life after death is a glorious one which will be beyond the faintest influence of death. His declaration of the salvation and the immortality of the soul brings him final triumphant over death.

Behtash (2017) also compare Donne's views on Death with those of the Persian poet Jalaluddin Rumi to find common grounds in their life and writings. The study denotes that both poets' lives were affected by the period of theological and political turmoil their countries witnessed. For both Donne and Rumi, Death and love were the major concerns in their minds and hearts as well as the main themes of their poetry. Both utilized colloquial language and far-fetched imagery to illuminate their subject. Employing surprising comparisons required sharp intellect, which both possessed. Behtash concludes that Death for these two great figures of the East and the West was union with the Origin of Existence; death was not a punishment but an incident everyone will and must endure. It is the passage through which one acquires eternity.

In another study, Babynet (2020) investigates John Donne's poem "The Dampe" as a work where death does not only appear as a mere thematic concern, but also appears as a poetic device. Babynet appreciates the extraordinary dramatic force and the extra-linguistic references that represent death within the Occidental cultural legacy which turns the subjectivity of the poetic voice into the subjectivity of the readers and links empirical as well as imaginative aspects of the poetic discourse creating sensual vividness. The poem exhibits the associative richness and the ability of death to create links between opposing ideas revealing the rhetorical power of this grim concept in the poetry of Donne. These new connotations, that evolve from semantic irrelevance on the denominative level, establish ambiguity into the poetic discourse and offer plentiful interpretative possibilities intensifying the meaning of the poem and deepening the aesthetic experience of its readers.

On the other hand, Death (Mawt) is a pivotal premise in Arabic poetry. Arabic poets from the classic pre-Islamic up till the modern era has tremendously reflect upon life and death in their poetry. Uncountable heart-rending poems and elegies are found in Arabic poetic volumes that romanticized death and surrendered to its mighty occurrence. Arabs saw life in all aspects of life; in the hard desert life, in the 
bloody tribal wars, in man's war with nature and in man's anguish while dying. Poet questioned the realty of life and death and the destiny of man after death. In the Islamic and the following ages, the concept of death started changing towards the spiritual side were death was treated as the end of the temporary painful life and the beginning of the promised joyful life in paradise.

Among such poets, Abul Alaa Al-Ma'arri (363-1058) stands prominently. Known as the "poet of philosophers and the philosopher of poets", he gains much popularity and esteem in Arabic literature. Abul Alaa lost his sight at a very young age, lost his parents at a young age, faced conspiracies and enmities from the literary circle around, faced financial issues, was isolated and expelled from society that he confined himself at home for more than forty years and was labeled as the "hostage of two prisons" referring to his blindness and alienation. This life of utter misery and deprivation played a causative role in forming his sights about life and death. After a long struggle with the hardships of life he died leaving behind priceless heritage of literature and philosophy such as Saqt AlZand "The Tinder Spark", Risalat AlGufran "The Epistle of Forgiveness" and the famous Luzumyat "Essences". His poetry rarely deviates the theme of death and mediations about life and existence. Life became gloomy and disappointing for Abul-Alaa that he preferred death to life, so all the sufferings may come to end. His poetry invites people to shun life and welcome death, so they can be delivered to the eternal life hereafter.

Al-Ma'arri's poetry has been attracting worldwide critics and reviewers with special focus on his philosophies about life and death. Ghazo'a (2016) scrutinizes AlMa'arri's views on Death both thematically and stylistically. She finds that his poetic experience about Death is unique in theme and style. She highlights the most famous extracts from his poetry where he questions life and death and ponders on the reality of Death presenting distinctive philosophies.

Ma'aroof (2018) similarly investigates the significance of the theory of life and death in the poetry of al-Ma'arri through the linguistic devices to reveal the semantic construction and its role in the production of semantic effectiveness and its creation in the text. After examining the relationship of signifier and meaning in the text of Al-Ma'ari, the study finds that we must start from the purely signifier, the term refers to the first meaning, which in turn may turn into a second dimension, which is then fragmented into infinite connotations governed by the status of the signifier in its textual relations with other functions - the context - producing the positive Sign of the text. The study finds that Al-Ma'arri's believe in the certainty of Death and his wonders about life after Death and even sometimes his awes and apprehensions which totally reflects the fluctuations of his belief and life circumstances.

Nabti (2019) tackles the theme of the dichotomy of life and death in AlMa'arri's poetry volume "Luzoomyat". Quoting examples from his death poems, Nabti explains his views about life as an imprisonment and seclusion of the human soul and Death as a relief and connection to the eternal life.

The aforementioned discussion shows a notable body of literature that is related to the thematic and stylistic features of Donne and Abul-Alaa Al-Ma'arri. 
However, no study till now has explored the mystic aspect of death in the poetry of these poets in a comparative method with focus on the thematic as well as the stylistic features. The current study is a comparative study of two various literatures on one theme. It cuts across the national boundaries and compare the themes and literary forms of the authors to discover the underlying elements of unity and getting universal knowledge of their poetry. The potentials of the selected death poetry can be recognized effectively by comparing.

\section{RESEARSCH METHOD}

This study is a descriptive analytical study that compares both poets qualitatively underneath the standpoint of literary studies, in which the data are taken from the selected poems by both poets that share the same idea. The instrument is the researcher herself who collected data by separating death poem which are the focus of the study, segregating the shared views then putting them in comparison with each other. Data analysis process was implemented by data content analysis method of the selected verses using related mystic principals. Descriptive analysis explanation is used to demonstrate these images and create meaning, and comparative analysis was used to bring the thematic and stylistic similarities and differences.

\section{RESULTS AND DISCUSSION}

The afore mentioned discussion brings out a huge resemblance in the life circumstances that lead both poets to the equivalent perception of Death that has a mystical tendency. A keen examination of the death related poems clearly shows that both poets have gone through logically sequential phases that lead them to a specific insight about death.

\section{Contemplation and the use of Imagery}

The first stage is contemplation which is, as Kugle states, the path that transforms heart by instilling spirituality and values in it deeply. To meditate and contemplate is the way to "draw God down to you and to allow yourself to be lifted up toward God". Donne and Aul-Alaa meditated on life and the harsh circumstances that made it undesired and unwanted, consequently death is welcomed and not feared as it will be a relief from this throttling life. There meditative insights are presented through imagery that appeals to the human senses. In one of his sermons, Donne, describes the image of life as constant scenes of sufferings. He states while remembering his long painful life where he lost his beloved ones and faced challenging health and financial issues:

\section{"I am the man that hath seen afflictions..."}

Quite similarly, Al-Ma'arri declares the harshness of his merciless life that could not give him but sufferings and miseries. He says in one of his poems:

$$
\text { فما وجدنا فبيه غبير الثقاره }
$$


We have tried all phases of life

And couldn't find in it but afflictions.

As stated before, both poets came into a world which was really stricken with anxieties and this urged them to seek an end to it. This has been expressed in a very simple colloquial language, direct imagery and a sober tone and pessimistic mood.

\section{Escapism and the use of Apostrophe}

The first stage of contemplation leads to escapism which offers refuge in a synthetic tranquility. It draws both poets to the fact that the pleasures and sins of this life have shut the doors of their hearts to God. They realized that such a life is not worth to be lived and death is preferred as it will put an end to these "sins". Donne is compromising with death and addresses Death with the use of apostrophe take over his "black soul":

\section{Oh! my black soul, now thou art summoned, By sickness death harled, and champion.}

Al-Ma'arri names death as a "luck" for the person whose words and deeds are calculated, and he shall be accounted for them:

$$
\begin{aligned}
& \text { الموت حظ لمن تأمله } \\
& \text { ولبيس في العبش أن تؤمل حظ تأل } \\
& \text { لاسيها الذي يخطّ علبه } \\
& \text { الوزر ان قال او رنا او لحظ لئ }
\end{aligned}
$$

Death is a luck for that who meditates it,

While there is no luck in living

Especially for that who commits,

Sins in words, looks and deeds.

In another place, Al-Ma'arri addresses the family and companions of the departing person to lay out his body in the graveyard and not to prolong keeping him in the coffin as that deprives him from the blessing of the affable companion, the soil:

$$
\begin{aligned}
& \text { يا هؤلاء اتركوه والثرى فله } \\
& \text { أنستّ وهو أولى صاحبّ صُحبا }
\end{aligned}
$$

O' those, leave him with the soil for it, Has geniality, and best companion to be accompanied is it.

Just like world's great mystic poets who lived and sung in times of turmoil and had the impulse to escape from the world in the search for otherworldliness, the ambience in Donne and Al-Ma'arri's lives paved the way to spiritual ecstasies 
and self-inflicted withdrawal from worldly matters. This resulted into a silent rebellion against the milieu and a revolt which invited a change within, rather than a change without. Hence interest in life and the desire to live longer vanished and an understanding with the reality of death was developed. The apostrophe has helped greatly in conveying the poets' emotion and allowing them better expression view to their inner thoughts and feelings as well as strengthening the idea by bringing life to an element that is not a present part of the situation and dragging the attention to the subject of Death and the idea of seeking rid of the sinful life and the thirst to be purified and loved by God.

\section{Compulsion and the use of Metaphor}

The next stage is compulsion where the self seeks pleasure from fulfilling desires and committing sins, then get the conscience of discriminating between good and evil. Donne and Al-Ma'arri have both been quoted for living self-centered phase of life against religion. This lead both poets to turn to be regretful, inspired, and conscious to confess their sins, admit their shortcomings and implore to their Lord to forgive them, to purify their souls from sins and facilitate going back to him. Addressing his God, Donne pathetically says:

Batter my heart, three-person'd God, for you

As yet but knock, breathe, shine, and seek to mend;

That I may rise and stand, o'erthrow me, and bend

Your force to break, blow, burn, and make me new.

Divorce me, untie or break that knot again,

Take me to you, imprison me, for l,

Except you enthrall me, never shall be free, Nor ever chaste, except you ravish me.

Likewise, Abul-Alaa prays in a heart touching monologue:

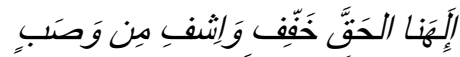

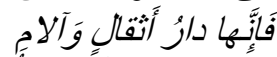

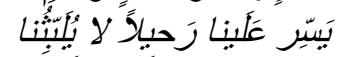

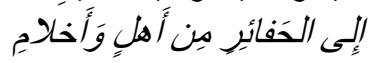

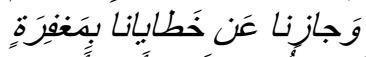

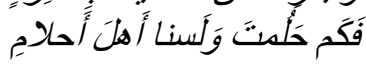

Our true lord, relieve and remove our sickness

Indeed, it's a life of burdens and pains

Facilitate departure from here

To graves, which won't spare any of family and fiends

And reward our sins with forgiveness

You've been easy-going with us, while we've been unwise.

This reawakening has been spelt out beautifully by Schimmel (2003). She declares that the self is overwhelmed in the "all embracing ocean of the Divine", and there is a necessity for the desire "for bringing the heart closer to God, to bring 
it, then, into communion with God, to lead it from the blind and fruitless acceptance of inherited truths to a participation in the life of the eternal" (Schimmel, 2003) Both poets have used a poignant metaphors and imploring words to reflect the inner distress, burdened hearts and upset minds. Donne uses an alchemic metaphor comparing his heart to a hard metal which needs to be battered hardly, exposed to heat, and modified properly to be able to take the shape of a refined gold. Al-Ma'arri compares his soul with a sick hampered person who cannot travel until he is relieved and treated. For both poets, souls are in a state of deterioration and both request their Lord to fix their souls and facilitate their departure to the life hereafter as they lost all interests in this deceitful temporary life. The use of metaphors fosters readers' imagination and enables the poets to convey their emotions and impressions about Death immemorably and effectively.

\section{Submission and the use of Personification}

The fourth stage is submission, accepting the reality and surrendering to its inevitability. Death is one of the horrible realities that has always been escaped, denied, questioned, and belied. Donne and Abul Alaa went against the stream and admitted that death is a reality, a destined end and a fated truth that shall face every single creature on earth. In Holy Sonnet XII Donne addresses death as a "slave for fat" that indicates that it is strongly associated with destiny which has been fated to all living beings:

Thou art slave for fate, chance...

Every creature comes to life for a specific span of time, but no matter how long they live, the ultimate end is death. Both death and life are controlled by fate, which is pre-decided, hence none has the choice to choose when, where and how much to live. This is what Al-Ma'arri tries to convey when he says:

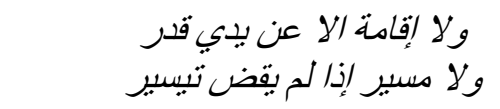

There is no life but as per destined

Nor death if it is not fated

Donne compares death to a slave to fate and chance and Al-Ma'arri asserts that death is a fate that will come as per destined. There is an underneath tone of sarcasm in associating death with fate and bounding its control with fate that causes it. No doubt, there is an element of awe in admitting the reality that Death is a merciless secret visitor who can visit anyone anytime and anywhere yet, and unlike other poets who romanticized and fascinated death, Donne and Al-Ma'arri realistically approached it. They compare it to a wild strong animal who insatiably attacks human to put an end to their lives. In one of his poems Donne says:

And gluttonous Death will instantly unjoin

My body, and soul... 
With the same figurative tone, Al-Ma'arri also declares his unshakeable faith that death is certain and universal:

$$
\begin{aligned}
& \text { والمنايا كالأسد تفرس } \\
& \text { الأحباء جمعا ل..... }
\end{aligned}
$$

And deaths are like lions that devour

Living beings together...

Both poets compared death to a voracious animal and people as helpless preys. The choice of this specific comparison has aptly conveyed the meaning of dreadfulness and inexorability of death.

In front of the destructive power of a harsh reality like death, life loses all charms and all pleasures vanish. Donne imagined the scene of death approaching him to make all his life enjoyments a story of the past when he says:

\section{Death meets me as fast, \\ And all my pleasures are like yesterday.}

Al-Ma'arri is also aware of the fact that no matter how long and joyful life is, death will surely eliminate these enjoyments in a blink of an eye:

$$
\begin{aligned}
& \text { ألا فانعدوا و/حذروا في الحياة }
\end{aligned}
$$

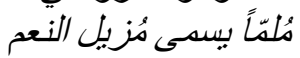

So, enjoy and fear in this life,

A calamity that is called the demolisher of pleasures.

There is a deep sense of melancholy and vulnerability under these submissive words, a very true wave of heartfelt emotions in a very simple language that penetrates the heart of the reader every time these lines are read. The use of personification has aided a lot in describing the non-human entity of Death in the most vivid and comprehensible way that contributes effectively in creating the meaning and fostering the imagination.

\section{Reception and the use of Symbolism}

The next stage is the tranquility and reception. Death is now a compromised reality, it is welcomed and not feared. Quite opposite to other poets who run and shun from death fearing its mighty strike which may overtake a person anytime anywhere regardless of his age, Donne now finds no terror in coming face to face with Death, rather he himself would like to run to it:

I run to death and death meets me as fast.

Parallel to Donne, Al-Ma'arri also announces his fearless and feelings towards Death saying:

$$
\text { إن يقرب الموت مني فلست أكره قربه }
$$

If death comes near to me, I don't hate its nearness. 
These revolutionary bold declarations of welcoming death and confronting it face to face instead of fearing and avoiding it clearly show the maturity of rationale and strength of faith which is a result of going through the previous sieving stages of intellectual elevation. To have a close perception of Death and to minimize its magnitude in human mind, Death is compared to natural human phenomena like sleep and drowsiness. In sleep, the body gets a chance to relax from the worldly fatigues and concerns and wake up later with freshness and vigor. Death is nothing but a sleep too which relieves the body from the anxieties and destitutions of this life and serves as a transformational stage from this temporary life to the eternal life hereafter where paradise will be waiting, and death will be no more then. In Donne's sonnet to death:

Rest and sleep, which but thy picture bee

Short sleep past, we wake eternally.

Al-Ma'arri reflects the same idea with more focus on the favor that Death will serve when it will help getting rid of a miserable like the one he had:

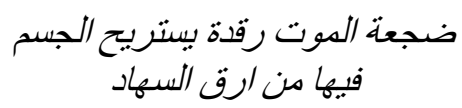

Death is a short sleep where body is

Eased from the tedious sleeplessness

For both Donne and Al-Ma'arri, Death and sleep are alike; they are inevitable, they are essential, they are comforters, they are continuation of being, and they are pathways to awakening which is better and eternal. The symbolic reference to Death by sleep adds significance and clarity to the notion and endows multiple layers of meanings to it.

\section{Union and the use of Allusion}

The last stage is the state of soul's entrenched urge for union of God, so death is considered as the best unifier with God and a path that leads to eternity in the life hereafter. Life with all its ups and downs was nothing but a distractor from God's path and separation from His blissful company. Death will serve as mediator between soul and God. Humans when born and come to life are separated from God, but when they die, they are reunited with Him again. Death is nothing to be mourned and lamented upon, it is a virtuous incident that should be welcomed as it connects the soul with its lord. As birth is welcomed, Death should be welcomed too. They are alike. Donne says:

Death and conception in mankind is one

Al-Ma'arri states in the beginning of his famous elegy:

$$
\text { وشبيةٌ صوت النعي إذا قبيس بصوت البشير في كل نادي }
$$

And if measured, voices of obituary of the dead and tidings of the new-born are similar. 
Coming to life with the burden of the body and soul is not less than suffering. When death comes, and the soul leaves the body to the realms of dimity and eternity, soul is relieved. Donne reflects this saying:

\section{I am a little world made cunningly \\ Of elements and angelic sprite \\ My worlds both parts and both parts must die}

Al-Ma'arri considers Death as a blessing which comforts the soul and the body as they get separated:

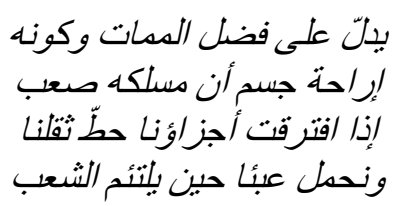

An indicator of the virtue of death

As a relief for the body that its path is hard

If our parts are segregated our burden is less, And we bear burden when our parts are collected.

God's slaves and best men don't die. Death is just a passage for them to infinity, to the life of paradise and endless blessings in God's company. This is the strongest mystic thought that has been reflected in Donne's poetry when he said:

"Rest of their bones, and soul's deliveries...."

Al-Ma'arri also emphasizes this aspect of death which makes it pleasant and welcomed:

$$
\text { إنما ينقلون من دار أعمال إلى دار شقوة أو رشاد }
$$

They moved from a temporary life of work to an eternal life of happiness or misery

The belief in resurrection and the life hereafter is fundamental behind this perception of death. Both Christianity and Islam assure the inevitability of death and the certainty of the life hereafter where there will be Paradise for pious good men and Hell for evil sinful ones. The use of theological allusion from Bible and Quran about the life Hereafter helps in demonstrating meaning and deepening meaning by giving extra context to the idea and developing a relationship between the poets' creation and its association with something else that they want the reader to recognize about Death.

The extracts discussed in the section above evidently manifest that Death has been redefined and philosophized in the poetry of John Donne and Abul Alaa AlMa'arri. Their views of death have gone through specific stages towards a distinct insight of death which is mystical in its core. Both poets pondered upon life, recognized death, experienced it around them, accepted it, submitted to it and embraced its spiritual perspective considering it as a passageway to the everlasting 
joyful life in heaven in the company of the Almighty. The major stylistic features of the poetry related to death are imagery, apostrophe, metaphors, personification, symbolism, and allusion. Thus, both poets masterfully triggered death as a theme for their artistic manufacture.

\section{CONCLUSION}

Abul Alaa Al-Ma'arri, the hostage of two prisons, and John Donne, the death poet, both experienced lives full of turmoil, deprivation, and religious, economic, and psychological instability. Life and death were major themes in their poetry. Their approach to death was not the archetypal approach based on magnifying and fearing death. They delved profounder in the philosophic and spiritual aspects of death and declared it as an agent that draws creatures back to God, and that is exactly the perception of death in mysticism. Both representatives of Arabic and English poetry considered death as the union with the origin of being, a reality that everyone shall face and go through to reach infinity. Both poets' death verses are not mere emotional flow or inadvertent sentimental expressions, but they are fullfledged verses in which words have been proficiently selected and the language has been beautifully controlled to generate mystical meaning with profundity of feeling, energy of ideas, immensity of knowledge, majesty of portrayal and splendor of the expression. The thematic and stylistic features that the study has explored where the logical construction of thought aided using figures like imagery, apostrophe, metaphors, personification, symbolism, and allusion which has evidently aided in bringing out the meaning, motivating the imagination and fostering critical thinking and grasping of the mystical perception. These stylistic devices are inventively used to accentuate the effect of the mystical perception about Death that both poets aimed to convey.

\section{REFERENCES}

Babynet, N. (2020). Death as Poetic Device in John Donne's The Dampe. Journal of Arts \& Humanities. Volume 7 - Issue 1. (3-16).

Bauman, Z. (1992). Mortality, Immortality and Other Life Strategies. Cambridge: Polity Press.

Behtash, E.Z. (2017). Images of Love and Death in John Donne and Sohrab Sepehri: A Comparative Study. International Journal of Applied Linguistics and English Literature.

Brooks, C and Robert P.W. (1943). Understanding Fiction. New York: AppletonCentury-Crofts.

Dickson, A. (2017). 'I am every dead thing': John Donne and death. British Library. https://www.bl.uk/shakespeare/articles/i-am-every-dead-thing-john-donneand-death

Donne, J. (2002). The complete poems of John Donne. London: Wordsworth Editions Limited.

Fomehshi (2013). The Concept of Death in John Donne and Sohrab Sepehri: A Comparative Study. Kata. Vol 15-2, (677-83).

Ghazo'a. H (2016). The Experience of Poetry in Luzumyaat by Alma'arry: Death as a Sample. The journal of social sciences and humanities, 4,43 . 
Ma'aroof, M. (2018). The Horizons of Significance in the poetry of Life and Death for Abul-Alaa al-Ma'arri. Shamsuddin. Journal of Scientific Research in Arts. Volume 19-7, (2-20).

McMahon, Frank, and Judith M. (1986). Psychology: The Hybrid Science. 5th ed. Chicago: The Dorsey Press.

Nabti, D. (2019). Duality of Life and Death in Abul-All Al-Ma'arri's Luzoomyat. Masters Thesis. University Qasidi Merbah Ouragla.

Oliver. A. (1999). Views of Death in Donne's Poetry. Luminarium: Anthology of English Literature. http://www.luminarium.org/sevenlit/oliver.htm

Patal. R. (2015). Re-critiquing/Redefining the Nature of Death: A Study of John Donne's 'Death Be Not Proud'. International Journal of Multidisciplinary Approach and Studies. Volume 02, No.2. (261-264).

Schimmel, A. (2003). Ben rüzgarım sen ateş: Mevlana Celaleddin Rumi (Trans. S. Özkan) [I am wind you are fire: The life and work of Rumi]. İstanbul, Turkey: Ötüken Neşriyat.

Sugg, R. (2007). John Donne: Critical issues. New York: Palgrave MacMillan.

Turki, I.M. (2003). Death Philosophy in Sufism. Alexandria: Darul-Wafa Publications.

Underhill, E. (1955). Mysticism: A study in the nature and development of man's spiritual consciousness. New York: Meridian Books. 